\title{
Low serum 25(OH)D levels are associated to higher BMI and metabolic syndrome parameters in adult subjects in Turkey
}

\author{
Guler Tosunbayraktar ${ }^{1}$, Murat Bas ${ }^{2}$, Altug Kut ${ }^{3}$, Aylin Hasbay Buyukkaragoz ${ }^{2}$
}

1. Baskent University, Health Sciences Faculty, Department of Nutrition and Dietetics, Ankara, Turkey

2. Acibadem University, Health Sciences Faculty, Department of Nutrition and Dietetics, Istanbul, Turkey

3. Baskent University, Department of Family Medicine, Faculty of Medicine, Ankara, Turkey

\begin{abstract}
Background: The aim of this study was to investigate the association of $25(\mathrm{OH}) \mathrm{D}$ levels with biochemical, anthropometric, and metabolic data obtained from normal and obese people.

Methods: This study was carried out on 90 individuals between the ages of 18 to 63 that had various body mass indexes. Blood samples and anthropometric measurements were taken.

Results: Waist circumferences, fat mass, LDL cholesterol levels, HDL cholesterol levels, 25(OH)D levels, and triglyceride levels were significantly different according to the body mass index groups of the participants $(p<0.05)$. When compared to the normal body mass index group, both other groups (overweight and obese) had higher waist circumferences, triglyceride levels, LDL cholesterol levels, fasting insulin levels, HOMA-IR ratios, parathyroid hormone levels, and fat mass, and had lower 25(OH)D levels $(\mathrm{p}<0.05)$. The overweight group participants had higher $25(\mathrm{OH}) \mathrm{D}$ levels than the obese group, and had lower waist circumferences, fat mass, fasting insulin level, HOMA-IR ratios, and HbA1C and PTH levels than those in the obese group $(\mathrm{p}<0.05)$.

Conclusion: In conclusion, the mean level of $25(\mathrm{OH}) \mathrm{D}$ is very low in overweight and obese individuals and low serum $25(\mathrm{OH}) \mathrm{D}$ levels appear to be associated with obesity, visceral obesity, hypertriglyceridemia, insulin resistance, and metabolic syndrome in obese patients.
\end{abstract}

Keywords: Obesity, vitamin D, metabolic syndrome

DOI: http://dx.doi.org/10.4314/ahs.v15i4.15

Cite as: Tosunbayraktar G, Bas M, Kut A, Buyukekaragoz. AH. Low serum 25(OH)D levels are associated to hrgher BMI and metabolic syndrome parameters in adults subjects in Turkey. Afri Health Sci. 2015;15(4):1161-9. bttp://dx.doi.org/10.4314/abs.v15i4.15

\section{Introduction}

$25(\mathrm{OH}) \mathrm{D}$ deficiency is an important public health problem in both developed and developing countries, with a reported worldwide prevalence of $30-80 \%$ in children and adults ${ }^{1-3}$. The role of $25(\mathrm{OH}) \mathrm{D}$ in bone mineralisation is well-documented. However, numerous recent studies have reported a link between $25(\mathrm{OH})$ $\mathrm{D}$ deficiency and several chronic disorders, such as type

\author{
Corresponding author: \\ Murat Bas, \\ Acıbadem University, \\ Health Sciences Faculty, \\ Department of Nutrition and Dietetics, \\ İçerenköy Mahallesi Kayışdağı Caddesi \\ No:32, Istanbul, Turkey. \\ Tel: +90 2165004230 \\ E-mail:murat.bas@acibadem.edu.tr
}

1 diabetes mellitus, systemic lupus erythematosus, multiple sclerosis, cardiovascular disease, and several malignancies ${ }^{4-6}$.

Positive associations between 25(OH)D deficiency and the prevalence of obesity have been shown. Recent studies in the adult population suggested that adequate serum $25(\mathrm{OH}) \mathrm{D}$ levels could be connected with increased adipocyte activity and oxidation of fat, as well as the potential for improving insulin sensitivity, which can lead to weight loss ${ }^{7,8}$. The synthesis and processing of $25(\mathrm{OH}) \mathrm{D}$ confirmed that obese patients have lower basal $25(\mathrm{OH}) \mathrm{D}$ and higher serum parathyroid hormone concentrations than do nonobese people ${ }^{9-11}$. Several studies have shown that obese individuals tend to have lower serum concentrations of vitamin $\mathrm{D}_{3}$ and $25(\mathrm{OH})$ $\mathrm{D}_{3}$ than those with normal weights ${ }^{9-12}$. For example, in one study, whole-body irradiation produced an increase in serum vitamin $\mathrm{D}_{3}$ levels in obese individuals [body 
mass index (BMI) $\left.30 \mathrm{~kg} / \mathrm{m}^{2}\right]$ that was $57 \%$ lower than that in age-matched, normal weight controls (BMI 25) ${ }^{13}$.

Since there is an inverse relationship between $25(\mathrm{OH})$ $\mathrm{D}$ levels, the degree of obesity ${ }^{14}$, and central adiposity ${ }^{15}$, it has been difficult to distinguish the independent effects of obesity and $25(\mathrm{OH}) \mathrm{D}$ on metabolic syndrome. Furthermore, it is not known whether the association between $25(\mathrm{OH}) \mathrm{D}$ deficiency and the metabolic syndrome is still present at very high degrees of obesity, in which the possible effect of $25(\mathrm{OH}) \mathrm{D}$ status on the metabolic syndrome could be ameliorated or even completely overcome by the predominant effect of obesity $^{16}$.

Several mechanisms have been proposed to explain the low $25(\mathrm{OH}) \mathrm{D}$ levels in obese people and include the sequestration of $25(\mathrm{OH}) \mathrm{D}$ by fat tissues ${ }^{17}$, as well as body size ${ }^{18}$. On the other hand, abnormal fasting serum or plasma lipid levels are the most prominent symptoms resulting from obesity ${ }^{19}$, and the effect of $25(\mathrm{OH})$ $\mathrm{D}$ supplementation on lipid profiles remains controversial $^{20}$.

Studies showed that in Turkey, 25(OH)D deficiency is an important problem. There have been few studies about obesity and $25(\mathrm{OH}) \mathrm{D}$ levels in the Turkish population $^{21,22}$. The aim of this study was to investigate the association of $25(\mathrm{OH}) \mathrm{D}$ levels and certain biochemical, antropometric, and metabolic data in normal and obese people.

\section{Methods}

\section{Study population}

This study was performed with the participation of 90 individuals between the ages of 18 and 63 with various BMIs that were admitted to the Endocrinology department of the Başkent University Ankara hospital's Ümitköy polyclinic from June to November 2013. They were healthy and thus did not have any health problems at the time of admission. People who were using any kind of medicines, vitamins, or minerals were not included in this study. Pregnant or lactating women, as well as people with a pre-diagnosed diseases or those diagnosed with a disease during the study period, were not excluded.

\section{Clinical and anthropometric characteristics}

Height, weight, waist and hip circumferences were measured from 08:00 to 10:00 hours after a $12 \mathrm{~h}$ fast.
Height was measured using a stadiometer accurate to $\pm 0.5 \mathrm{~cm}$, and weight was obtained with participants wearing light clothing and no shoes using a calibrated scale, accurate to $\pm 0.1 \mathrm{~kg}$ (Filizola S.A., São Paulo, SP, Brazil). The BMI was calculated using the standard equation (kilograms per meters squared). The waist circumference was measured with participants in the standing position, midway between the lower margin of the last rib and the iliac crest, at mid exhalation. The hip circumference was measured at the widest point of the hip/buttocks area with the measuring tape parallel to the floor. The waist-to-hip ratio was determined by dividing waist circumference by hip circumference. Anthropometric measurements were taken twice, and the mean values were used in all analyses. Systolic blood pressure (SBP) and diastolic blood pressure (DBP) were measured twice in the sitting position, with $15 \mathrm{~min}$ between the measurements, using standard sphygmomanometers of appropriate width, after a rest period for $30 \mathrm{~min}$.

\section{Biochemical analysis}

The percentage of body fat was estimated by electrical bioimpedance using a Jawon IOI 353 body fat analyser (Biodynamics Corp., Seattle, WA, USA). We stratified adiposity as global adiposity (excessive adipose tissue, independent of site) and abdominal adiposity. BMI and percentage of body fat were used as global adiposity parameters. The waist circumference and waist-to-hip ratio were used to evaluate abdominal adiposity. Blood samples were collected after a $12 \mathrm{~h}$ fasting period. Biochemical evaluation included glucose, total cholesterol, high-density lipoprotein cholesterol, low-density lipoprotein cholesterol, triacylglycerols, calcium, phosfor, HbA1C, parathyroid hormone (PTH), and 25(OH)D.

Fasting plasma glucose, total cholesterol, HDL-cholesterol, LDL-cholesterol, TG, HbA1C, and calcium levels were measured using original kits and an Abbott-Aeroset autoanalyser (Architect C-8000, Chicago, Illinois, USA). Parathyroid hormone and fasting plasma insulin levels were measured using original kits using an Perfect Plus 400 autoanalyser (Mindray, UK). Insulin resistance was estimated from fasting serum measurements using the homeostasis model assessment-insulin resistance (HOMA-IR) [insulin $(\mu \mathrm{U} / \mathrm{mL})$ X glucose $(\mathrm{mg} / \mathrm{dL}) \div$ 425]. Metabolic syndrome was diagnosed according to NCEPATP III $^{23}$. Thus, a participant had MS if he or she had three or more of the following: (i) abdominal obesity: waist circumference $>102 \mathrm{~cm}$ in men and $>88$ 
$\mathrm{cm}$ in women; (ii) plasma triglycerides: $\geq 150 \mathrm{mg} / \mathrm{dL}$; (iii) plasma HDL cholesterol: $<40 \mathrm{mg} / \mathrm{dL}$ in men and $<50 \mathrm{mg} / \mathrm{dL}$ in women; (iv) SBP: $\geq 130 \mathrm{mmHg}, \mathrm{DBP}$ : $\geq 85 \mathrm{mmHg}$, or the use of antihypertensive medicine; (v) plasma glucose: $\geq 110 \mathrm{mg} / \mathrm{dL}$ or the use of antidiabetic medicine/insulin.

\section{Statistical analysis}

Data are reported as mean $\pm S D$ for continuous variables and as numbers or a percentage for categorical variables. Clinical and biochemical characteristics were compared using the Student's $t$ test or the chi-square test when the variables were continuous or categorical, respectively. The Pearson correlation test was used to evaluate associations between serum 25(OH)D and components of anthropometric and metabolic syn- drome. Statistical analyses were performed using SPSS software, version 16.0 (SPSS Inc., Chicago, IL, USA).

\section{Results}

Waist circumferences, fat mass, and LDL cholesterol, HDL cholesterol, 25(OH)D, and triglyceride levels were significantly different according to the BMI groups of the participants $(\mathrm{p}<0.05$; Table 1$)$. When compared to the normal BMI group, both other groups (overweight and obese) had lower waist circumference, triglyceride levels, LDL cholesterol levels, fasting insulin levels, HOMA-IR ratios, parathyroid hormone levels, and fat mass, and had higher 25(OH)D levels $(\mathrm{p}<0.05)$. The overweight group had higher 25(OH)D levels than obese group, and had lower waist circumferences, fat masses, fasting insulin levels, HOMA-IR ratios, and HbA1C and PTH levels than the obese group $(\mathrm{p}<0.05)$.

Table 1. Changes in biochemical and anthropometric indices between BMI classifications

\begin{tabular}{|c|c|c|c|c|c|c|c|}
\hline \multirow[t]{2}{*}{ Variables } & \multicolumn{2}{|c|}{$\begin{array}{l}\text { Normal } \\
(n=30)\end{array}$} & \multicolumn{2}{|c|}{$\begin{array}{l}\text { Overweight } \\
(n=30)\end{array}$} & \multicolumn{2}{|c|}{$\begin{array}{l}\text { Obese } \\
(\mathrm{n}=30)\end{array}$} & \multirow[t]{2}{*}{$p$} \\
\hline & Mean & SD & Mean & SD & Mean & SD & \\
\hline Age (year) & 31.8 & 6.9 & 36.5 & 10.0 & 36.1 & 8.7 & a, b, c $p<0.05$ \\
\hline BMI $\left(\mathrm{kg} / \mathrm{m}^{2}\right)$ & 22.1 & 2.1 & 26.4 & 1.3 & 33.1 & 3.2 & $\mathrm{a}, \mathrm{b}, \mathrm{c} \mathrm{p}<0.05$ \\
\hline $\mathrm{WC}(\mathrm{cm})$ & 78.6 & 7.5 & 88.9 & 6.7 & 103.6 & 10.7 & a, b, c $\mathrm{p}<0.05$ \\
\hline DBP & 72.3 & 7.3 & 72.0 & 9.0 & 82.5 & 7.4 & ${ }^{\mathrm{b}, \mathrm{c}} \mathrm{p}<0.05$ \\
\hline SBP & 109.3 & 8.3 & 108.3 & 11.8 & 124.8 & 12.1 & ${ }^{b,}{ }^{1} \mathrm{p}<0.05$ \\
\hline Fat mass (kg) & 15.1 & 3.8 & 21.4 & 5.8 & 34.9 & 6.6 & $\mathrm{a}, \mathrm{b}, \mathrm{c} \mathrm{p}<0.05$ \\
\hline Fat mass $(\%)$ & 22.8 & 5.8 & 28.8 & 5.6 & 33.8 & 5.4 & a, b, c $\mathrm{p}<0.05$ \\
\hline Fasting glucose $(\mathrm{mg} / \mathrm{dL})$ & 90.2 & 8.1 & 93.6 & 8.0 & 96.4 & 9.9 & ${ }^{\mathrm{b}} \mathrm{p}<0.05$ \\
\hline $\mathrm{TC}(\mathrm{mg} / \mathrm{dL})$ & 172.7 & 29.4 & 183.5 & 37.6 & 196.4 & 40.3 & ${ }^{\mathrm{b}} \mathrm{p}<0.05$ \\
\hline LDL-C (mg/dL) & 106.3 & 24.0 & 125.8 & 33.0 & 133.5 & 35.6 & ${ }^{\mathrm{a}, \mathrm{b}} \mathrm{p}<0.05$ \\
\hline HDL-C (mg/dL) & 52.9 & 12.3 & 44.6 & 13.3 & 44.2 & 8.8 & a, ${ }^{2} p<0.05$ \\
\hline $\mathrm{TG}(\mathrm{mg} / \mathrm{dL})$ & 90.2 & 44.0 & 142.5 & 61.9 & 127.0 & 65.9 & a, ${ }^{p} p<0.05$ \\
\hline Fasting insulin $(\mu \mathrm{U} / \mathrm{mL})$ & 7.0 & 2.9 & 8.1 & 3.0 & 12.8 & 3.9 & ${ }^{b, c} \mathrm{p}<0.05$ \\
\hline HOMA-IR ratio & 1.6 & 0.7 & 1.9 & 0.7 & 3.1 & 1.1 & ${ }^{b, c} \mathrm{p}<0.05$ \\
\hline $\mathrm{HbA1C}(\%)$ & 5.2 & 0.5 & 5.3 & 0.5 & 5.7 & 0.7 & $\mathrm{~b}, \mathrm{c} p<0.05$ \\
\hline $25(\mathrm{OH}) \mathrm{D}(\mu \mathrm{g} / \mathrm{L})$ & 27.5 & 8.3 & 21.3 & 5.8 & 16.2 & 4.4 & a, c $\mathrm{p}<0.05$ \\
\hline Blood Ca $(\mathrm{mg} / \mathrm{dL})$ & 9.5 & 0.4 & 9.3 & 0.3 & 9.3 & 0.3 & ${ }^{\mathrm{b}} \mathrm{p}<0.05$ \\
\hline PTH $(\mathrm{pg} / \mathrm{mL})$ & 40.1 & 16.8 & 42.5 & 15.0 & 52.8 & 23.0 & ${ }^{\mathrm{b}, \mathrm{c}} \mathrm{p}<0.05$ \\
\hline
\end{tabular}

BMI, body mass index;WC, waist circumference; BP, blood pressure; HDL-C, high density lipoproteincholesterol; LDL-C, low density lipoprotein-cholesterol; TG, triglyceride; Ca, calcium; and PTH, parathyroid hormone.

${ }^{a}$ significant diffrences between normal weight and overweight $(\mathrm{p}<0.05)$.

${ }^{b}$ significant diffrences between normal weight and obese $(p<0.05)$.

${ }^{c}$ significant diffrences between overweight and obese $(p<0.05)$. 
Table 2 lists the clinical and biochemical characteristics of the participants separated according to $25(\mathrm{OH}) \mathrm{D}$ levels: $<20 \mathrm{ng} / \mathrm{mL}$ (deficiency) and $\geq 20 \mathrm{ng} / \mathrm{mL}$ (sufficiency). The mean TG and HDL-C level was significantly different in the sufficiency group than in the deficiency group $(\mathrm{p}<0.05)$. The deficiency group had slightly higher mean blood PTH, TC, LDL-C, TG, and fasting glucose levels when compared to those in the sufficiency group, although this trend was not statistically significant ( $p>0.05)$. The mean BMI, WC, fat mass, fasting insulin levels, HOMA-IR ratios, and HbA1C, DPB, and SBP levels were significantly lower in the sufficiency group than in the deficiency group $(p<0.05)$.

Table 2. Characteristics of participants based on serum 25(OH)D concentrations

\begin{tabular}{lccccc}
\hline & \multicolumn{3}{c}{$\begin{array}{c}\text { Suficient }(\mathrm{n}=44) \\
\geq 20 \mu \mathrm{g} / \mathrm{L}\end{array}$} & $\begin{array}{c}\text { Deficiency }(\mathrm{n}=46) \\
<20 \mu \mathrm{g} / \mathrm{L}\end{array}$ & $p$ \\
\hline Metabolic syndrome & \multicolumn{2}{c}{$4(9.0 \%)$} & \multicolumn{2}{c}{$12(26.1 \%)$} & $0.032^{*}$ \\
\hline & Mean & S.D. & Mean & S.D. & \\
\hline BMI $\left(\mathrm{kg} / \mathrm{m}^{2}\right)$ & 25.7 & 4.5 & 28.7 & 5.2 & $0.005^{*}$ \\
WC $(\mathrm{cm})$ & 86.6 & 11.1 & 94.0 & 14.3 & $0.008^{*}$ \\
Fat Mass $(\mathrm{kg})$ & 20.3 & 6.7 & 27.2 & 10.8 & $0.000^{*}$ \\
TC $(\mathrm{mg} / \mathrm{dL})$ & 178.1 & 34.7 & 190.2 & 38.6 & 0.131 \\
LDL-C $(\mathrm{mg} / \mathrm{dL})$ & 117.0 & 31.2 & 126.5 & 34.3 & 0.174 \\
HDL-C $(\mathrm{mg} / \mathrm{dL})$ & 48.6 & 11.2 & 43.1 & 10.6 & 0.017 \\
TG $(\mathrm{mg} / \mathrm{dL})$ & 107.1 & 60.4 & 141.9 & 66.9 & $0.012 *$ \\
Fasting glucose $(\mathrm{mg} / \mathrm{dL})$ & 92.9 & 9.2 & 93.9 & 8.8 & 0.615 \\
Fasting insulin $(\mu \mathrm{U} / \mathrm{mL}$ & 8.0 & 3.3 & 10.6 & 4.5 & $0.003 *$ \\
HOMA-IR ratio & 1.9 & 0.8 & 2.5 & 1.2 & $0.006 *$ \\
HbA1C $(\%)$ & 5.3 & 0.5 & 5.6 & 0.7 & $0.011 *$ \\
Diatolic BP $(\mathrm{mmHg})$ & 73.3 & 8.8 & 77.8 & 9.2 & $0.019 *$ \\
Sistolic BP $(\mathrm{mmHg})$ & 110.5 & 10.8 & 117.7 & 14.3 & $0.008 *$ \\
25(OH)D $(\mu \mathrm{\mu g} / \mathrm{L})$ & 27.7 & 6.4 & 15.9 & 3.6 & $0.000 *$ \\
Blood Ca $(\mathrm{mg} / \mathrm{dL})$ & 9.4 & 0.4 & 9.3 & 0.3 & 0.449 \\
PTH $(\mathrm{pg} / \mathrm{mL})$ & 43.6 & 18.0 & 46.6 & 20.4 & 0.457 \\
\hline
\end{tabular}

BMI, body mass index; WC, waist circumference; BP, blood pressure; HDL-C, high density lipoprotein-cholesterol; $L D L-C$, low density lipoprotein-cholesterol; TG, triglyceride; Ca, calcium; and PTH, parathyroid hormone.

* significantly different between the two groups $(p<0.05)$.

The Pearson's correlation coefficients (r) for selected baseline variables are shown in Table 3. At baseline, $25(\mathrm{OH}) \mathrm{D}$ levels correlated inversely with BMIs $(\mathrm{r}=$
$-0.469 ; \mathrm{p}=0.000)$, waist circumferences $(\mathrm{r}=-0.432$; $\mathrm{P}=0.000)$, fat masses $(\mathrm{r}=-0.419 ; \mathrm{p}=0.004)$, fasting insulin levels $(\mathrm{r}=-0.432 ; \mathrm{p}=0.000)$, and HOMA-IR $(\mathrm{r}$ $=-0.341 ; \mathrm{p}=0.001)$. 
Table 3. Relationship between serum 25(OH)D levles and anthropometric and metabolic risk factors

\begin{tabular}{|c|c|c|c|c|c|c|c|c|c|}
\hline & \multicolumn{3}{|c|}{ Total $(n=90)$} & \multicolumn{3}{|c|}{ Female $(n=45)$} & \multicolumn{3}{|c|}{ Male $(n=45)$} \\
\hline & VIT D & $\mathrm{Ca}$ & PTH & VIT D & $\mathrm{Ca}$ & PTH & VIT D & $\mathrm{Ca}$ & PTH \\
\hline $\begin{array}{l}\text { BMI } \\
\left(\mathrm{kg} / \mathrm{m}^{2}\right)\end{array}$ & $\begin{array}{c}- \\
0.469 * *\end{array}$ & $-0.234^{*}$ & $0.320 * *$ & $\begin{array}{c}- \\
0.519^{* *}\end{array}$ & -0.244 & 0.266 & $\begin{array}{c}- \\
0.417 * *\end{array}$ & -0.242 & $0.373^{*}$ \\
\hline $\mathrm{WC}(\mathrm{cm})$ & $\stackrel{-}{-} \cdot 432^{* *}$ & -0.105 & 0.195 & 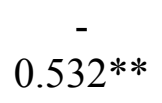 & -0.172 & 0.173 & $\stackrel{-}{-} \cdot 407^{* *}$ & -0.192 & 0.232 \\
\hline $\begin{array}{l}\text { DBP } \\
(\mathrm{mmHg})\end{array}$ & $\stackrel{-}{-}$ & -0.138 & 0.108 & $-0.342 *$ & -0.278 & 0.070 & -0.215 & 0.026 & 0.156 \\
\hline $\begin{array}{l}\text { SBP } \\
(\mathrm{mmHg})\end{array}$ & $\stackrel{-}{-}$ & $\overline{-}^{-}$ & 0.162 & $-0.359 *$ & $\begin{array}{c}- \\
0.397 * *\end{array}$ & 0.107 & -0.235 & -0.152 & 0.234 \\
\hline $\begin{array}{l}\text { TC } \\
(\mathrm{mg} / \mathrm{dL})\end{array}$ & -0.172 & 0.008 & -0.079 & -0.089 & 0.098 & -0.056 & -0.274 & -0.079 & -0.102 \\
\hline $\begin{array}{l}\text { LDL-C } \\
(\mathrm{mg} / \mathrm{dL})\end{array}$ & -0.183 & -0.092 & 0.002 & -0.096 & 0.009 & 0.086 & $-0.298 *$ & -0.244 & -0.103 \\
\hline $\begin{array}{l}\text { HDL-C } \\
(\mathrm{mg} / \mathrm{dL})\end{array}$ & 0.144 & $0.248^{*}$ & -0.150 & 0.208 & $0.373^{*}$ & -0.191 & 0.105 & $0.298^{*}$ & -0.110 \\
\hline $\begin{array}{l}\text { TG } \\
(\mathrm{mg} / \mathrm{dL})\end{array}$ & -0.129 & 0.023 & 0.025 & -0.193 & 0.042 & -0.040 & -0.062 & -0.066 & 0.066 \\
\hline $\begin{array}{l}\text { Fat mass } \\
(\mathrm{kg})\end{array}$ & $\overline{-}^{-}$ & -0.258 & $0.333^{*}$ & $\stackrel{-}{-}^{-} .523^{* *}$ & -0.242 & 0.225 & $\overline{-}^{-} .419^{* *}$ & -0.258 & $0.333^{*}$ \\
\hline $\begin{array}{l}\text { Fasting } \\
\text { glucose } \\
(\mathrm{mg} / \mathrm{dL})\end{array}$ & -0.173 & -0.067 & 0.143 & -0.163 & -0.169 & 0.092 & -0.176 & -0.029 & 0.187 \\
\hline $\begin{array}{l}\text { Fasting } \\
\text { insulin } \\
(\mu \mathrm{U} / \mathrm{mL})\end{array}$ & $\overline{-}-\overline{346 * *}$ & -0.090 & $0.303 * *$ & $\begin{array}{c}- \\
0.466^{* *}\end{array}$ & $-0.345^{*}$ & $0.342 *$ & -0.282 & 0.007 & $0.298^{*}$ \\
\hline $\begin{array}{l}\text { HOMA- } \\
\text { IR ratio }\end{array}$ & $\overline{-}^{-}$ & -0.087 & $0.288 * *$ & $\overline{-}^{-} \cdot 486^{* *}$ & $-0.369 *$ & $0.348^{*}$ & $-0.287 *$ & -0.007 & $0.284^{*}$ \\
\hline $\begin{array}{l}\mathrm{HbA1C} \\
(\%)\end{array}$ & $-0.261 *$ & -0.148 & -0.115 & $-0.346^{*}$ & -0.213 & -0.066 & -0.130 & -0.160 & -0.205 \\
\hline
\end{tabular}

BMI, body mass index; WC, waist circumference; BP, blood pressure; HDL-C, high density lipoprotein-cholesterol; LDL-C, low density lipoprotein-cholesterol; TG, triglyceride; Ca, calcium; and PTH, parathyroid hormone.

$* \mathrm{p}<0.05$

$* * \mathrm{p}<0.01$

\section{Discussion}

$25(\mathrm{OH}) \mathrm{D}$ deficiency is increasingly being recognised worldwide ${ }^{2,24}$. There have been prevalence studies on $25(\mathrm{OH}) \mathrm{D}$ deficiency and/or insufficiency in the Turkish population ${ }^{25}$, and most have been performed on women, people in nursing homes, and the elderly ${ }^{26-28}$. Also, obesity leads to many health problems worldwide. It is a major public health problem and the most common nutritional disorder ${ }^{29}$. It is related to a host of health problems. In particular, abdominal obesity is associated with some serious problems, such as type 2 diabetes, cardiovascular and cerebrovascular diseases, hypertension, digestive disorders, and cancer $^{30}$. The highest mean prevalence of obesity is $32.05 \%$ and was reported in the TEKHARF (men, 21.1\%; women, $43.0 \%$ ). The highest obesity frequency in women was also reported in this study $(43.0 \%)$. The mean obesity in the TURDEP was $22.3 \%$ (men, $12.9 \%$; women, $29.9 \%)^{31}$. Obesity is usually correlated with a higher prevalence of hypovitaminosis or a lower circulating 
25(OH)D level ${ }^{32,33}$. However, in the present study, the prevalence of $25(\mathrm{OH}) \mathrm{D}$ deficiency was higher in the overweight and obese groups than in the normal weight group. Over the past few decades, research has shown positive and negative associations between weight loss and maintenance with increased $25(\mathrm{OH}) \mathrm{D}$ and calcium intake (particularly with dairy products) in adults ${ }^{34-36}$. Additionally, studies have demonstrated links between a high BMI and decreased sun exposure, as well as decreased 25(OH)D levels ${ }^{37}$.

Previous studies have shown this association between $25(\mathrm{OH}) \mathrm{D}$ deficiency and metabolic syndrome in wom$e^{14}$ and in the general population ${ }^{15}$, and our present findings confirm these results also in overweight and obese people. Pittas et al. reported that the risk for developing type 2 diabetes was lower for those whose $25(\mathrm{OH}) \mathrm{D}$ levels were higher ${ }^{38}$. On the other hand, in a study carried out in postmenopausal women, it has been reported that low 25(OH)D levels were not associated with a risk of developing diabetes ${ }^{39}$. In our study, the serum $25(\mathrm{OH}) \mathrm{D}$ deficieny was associated with high fasting insulin levels and hyperparathyroidism. In cross-sectional and epidemiological studies, the relationship of $25(\mathrm{OH}) \mathrm{D}$ deficiency with DM type I, metabolic syndrome, obesity, cardiovascular diseases, hypertension, and mortality, possibly due to the role of this vitamin in insulin resistance, secretion, and inflammatory processes, were reported ${ }^{40-43}$. It has also been shown that deficiencies in serum $25(\mathrm{OH}) \mathrm{D}$ levels decreases insulin secretion by reducing calcium absorption and, therefore, causing secondary hyperparathyroidism and increased peripheral insulin resistance ${ }^{44}$.

The most promising study to date suggesting that $25(\mathrm{OH}) \mathrm{D}$ alters diabetes risk is a post hoc analysis from an osteoporosis intervention study in which 314 nondiabetic white adults were randomised to groups recieving either $700 \mathrm{IU}$ of the vitamins D3 and 500 $\mathrm{mg}$ calcium citrate or placebos daily for 3 years. Treatment with $25(\mathrm{OH}) \mathrm{D}$ and calcium citrate demonstrated attenuated increases in fasting glucose in participants with baseline impaired fasting glucose (IFG), but not in those with normal fasting glucose. Participants with IFG who received $25(\mathrm{OH}) \mathrm{D}$ and calcium also had reduced progression of insulin resistance, as assessed by HOMA-IR ${ }^{45}$. Conversely, a Women's Health Initiative (WHI) study reported that daily supplementation with
400 IU of vitamin D3 and $1000 \mathrm{mg}$ of calcium did not reduce risk of developing diabetes over 7 years, when compared to placebo ${ }^{46}$. In the present study, we found a significant difference between $25(\mathrm{OH}) \mathrm{D}$ deficient individuals and those with normal 25(OH)D level regarding HOMA-IR and HbA1c levels. This is in agreement with Chiu et al., who observed a positive relationship between $25(\mathrm{OH}) \mathrm{D}$ status and insulin sensitivity index in adults. In addition, they showed that $25(\mathrm{OH}) \mathrm{D}$ levels were negatively correlated with both first and second phase insulin responses during a hyperglycemic clamp and glucose levels during the oral glucose tolerance test. Therefore, they suggested that subjects with hypovitaminosis D not only displayed impaired $\beta$-cell function, causing impaired glucose homeostasis, but were also at increased risk of developing insulin resistance and metabolic syndrome when compared with vitamin D sufficient subjects ${ }^{47}$. Also, previous studies showed that serum $25(\mathrm{OH})$ D levels were inversely correlated with $\mathrm{HbA1c}$, independent of body fat, implying higher ambient glucose concentrations in children with lower 25(OH)D concentrations ${ }^{48,49}$.

Previous studies showed an inverse relationship between $25(\mathrm{OH}) \mathrm{D}$ levels and $\mathrm{BMI}^{14}$, as well as central adiposity ${ }^{15}$, making it difficult to distinguish the separate contributions of obesity and of $25(\mathrm{OH}) \mathrm{D}$ to the development of metabolic syndrome. Similarly, our findings indicated that a low $25(\mathrm{OH}) \mathrm{D}$ level is associated with a high BMI and central obesity. In contrast, Botella-Carratero et al. ${ }^{16}$ reported that patients with and without $25(\mathrm{OH}) \mathrm{D}$ deficiency had similar BMIs and waist circumferences, so the differences in metabolic syndrome prevalence and lipid levels may indeed reflect a true association between $25(\mathrm{OH}) \mathrm{D}$ status and the metabolic syndrome, irrespective of adiposity.

Low serum $25(\mathrm{OH}) \mathrm{D}$ was associated with components of the metabolic syndrome, including abdominal obesity, hypertension, hypertriglyceridemia, and higher $\mathrm{HbA} 1 \mathrm{C}$ and lower high-density cholesterol ${ }^{50}$. In the present study, we found that low serum vitamin D levels related to high abdominal obesity, high body fat, hypertriglyceridemia, and lower high-density cholesterol. Two cross-sectional studies (NHANES III and NHANES 2003-2004) showed a significant inverse association between serum $25(\mathrm{OH}) \mathrm{D}$ concentrations and metabolic syndrome ${ }^{15,51}$. 
In the current study, PTH levels correlated positively with BMI, fat mass, HOMA-IR ratio and fasting insulin levels. The association of PTH with impaired glucose tolerance is part of a newly proposed mechanism underlying the development of the metabolic syndrome ${ }^{51}$. Other studies have also suggested that individuals with hyperparathyroidism have an increased risk of developing type 2 diabetes ${ }^{52}$. Serum parathyroid concentrations have an important role in the mechanism of insulin resistance. Lee et al. shown that vitamin D levels are negatively correlated with metabolic syndrome frequency independent of serum parathyroid levels ${ }^{53}$. Hyperparathyriodism secondary to decrease in serum $25(\mathrm{OH}) \mathrm{D}$ levels was thought to be the main mechanism causing insulin resistance ${ }^{54}$. In a study conducted with 1017 morbid obese, Caucasian, male and female subjects, parathormone levels were found to be the only predictor of metabolic syndrome rather than vitamin D levels ${ }^{55}$.

\section{Limitations}

This study had some limitations. The main one being the cross-sectional nature of this study, with no causality effect to report. The sunlight exposure and effect of $25(\mathrm{OH}) \mathrm{D}$ supplementation on weight gain also need to be considered.

\section{Conclusion}

The mean level of $25(\mathrm{OH}) \mathrm{D}$ is very low in overweight and obese indiviuals, and low serum $25(\mathrm{OH}) \mathrm{D}$ levels appear to be associated with obesity, visceral obesity, hypertriglyceridemia, insulin resistance, and metabolic syndrome in obese individuals. A broad-based effort to prevent $25(\mathrm{OH}) \mathrm{D}$ deficiency in Turkey should be undertaken.

\section{References}

1. Calvo MS, Whiting SJ, Barton CN. Vitamin D intake: a global perspective of current status. J Nutr. 2005;135:310-316 PubMed .

2. Holick MF. Vitamin D deficiency. N Engl J Med. 2007;357:266- 281 PubMed . doi: 10.1056/NEJM$\mathrm{ra} 070553$

3. Oren Y, Shapira Y, Agmon-Levin N, Kivity S, Zafrir Y, Altman A, Lerner A, Shoenfeld Y. Vitamin D insufficiency in a sunny environment: a demographic and seasonal analysis. Isr Med Assoc J. 2010;12:751-756 PubMed .

4. Amital H, Szekanecz Z, Szucs G, Danko K, Nagy E, Csepany T, Kiss E, Rovensky J, Tuchynova A, Kozakova D, Doria A, Corocher N, Agmon-Levin N,
Barak V, Orbach H, Zandman- Goddard G, Shoenfeld Y. Serum concentrations of $25-\mathrm{OH}$ vitamin $\mathrm{D}$ in patients with systemic lupus erythematosus (SLE) are inversely related to disease activity: is it time to routinely supplement patients with SLE with vitamin D? Ann Rheum Dis. 2010;69:1155-1157 PubMed . doi: 10.1136/ ard.2009.120329.

5. Ascherio A, Munger KL, Simon KC. Vitamin D and multiple sclerosis. Lancet Neurol. 2010;9:599-612. doi: 10.1016/S1474-4422(10)70086-7.

6. Trump DL, Deeb KK, Johnson CS. Vitamin D: considerations in the continued development as an agent for cancer prevention and therapy. Cancer J. 2010;16:1-9 PubMed . doi: 10.1097/PPO.0b013e3181c51ee6.

7. Rosenblum JL, Castro VM, Moore CE, Kaplan LM. Calcium and vitamin D supplementation is associated with decreased abdominal visceral adipose tissue in overweight and obese adults. Am. J. Clin. Nutr. 2012;95(1):101-108. doi: 10.3945/ajcn.111.019489.

8. Mai X-M, Chen Y, Camargo CA Jr, Langhammer A. Cross-Sectional and Prospective Cohort Study of Serum 25-Hydroxyvitamin D Level and Obesity in Adults: The HUNT Study. American Journal of Epidemiology. 2012. doi: 10.1093/aje/kwr456.

9. Compston JE, Vedi S, Ledger JE, Webb A, Gazet JC, Pilkington TRE. Vitamin D status and bone histomorphometry in gross obesity. Am J Clin Nutr. 1981;34:2359- PubMed ;63.

10. Hey H, Stockholm KH, Lund BJ, Sorensen OH. Vitamin D deficiency in obese patients and changes in circulating vitamin $\mathrm{D}$ metabolites following jejunoileal bypass. Int J Obes. 1982;6:473-9.

11. Hyldstrup L, Andersen T, McNair P, Breum L, Transbol I. Bone metabolism in obesity: changes related to severe overweight and dietary weight reduction. Acta Endocrinol. 1993;129:393- PubMed ;8.

12. Bell NH, Epstein S, Greene A, Shary J, Oexmann MJ, Shaw S. Evidence for alteration of the vitamin D-endocrine system in obese subjects. J Clin Invest. 1985; 76: 370- PubMed ;373.

13. Liel Y, Ulmer E, Shary J, Hollis BW, Bell NH. Low circulating vitamin D in obesity. Calcif Tissue Int. 1988; 43: 199- PubMed ;201.

14. Liu S, Song Y, Ford ES, Manson JE, Buring JE, Ridker PM. Dietary calcium, vitamin D, and the prevalence of metabolic syndrome in middle-aged and older US women. Diabetes Care. 2005;28: 2926- PubMed ;32.

15. Ford ES, Ajani UA, McGuire LC, Liu S. Concentrations of serum vitamin $\mathrm{D}$ and the metabolic syndrome among US adults. Diabetes Care. 2005;28:1228- PubMed ;30. 
16. Botella-Carretero JI, Alvarez-Blasco F, Villafruela JJ, Balsa JA, Vázquez C, Escobar-Morreale HF: Vitamin $\mathrm{D}$ deficiency isassociated with the metabolic syndrome in morbid obesity. Clin Nutr. 2007; 26: 573-580.

17. Wortsman J, Matsuoka LY, Chen TC, et al. Decreased bioavailability of vitamin $\mathrm{D}$ in obesity. $\mathrm{Am} \mathrm{J}$ Clin Nutr. 2000; 72, 690-3 PubMed .

18. Drincic AT, Armas LA, Van Diest EE, et al. Volumetric dilution, rather than sequestration best explains the low vitamin d status of obesity. Obesity (Silver Spring). 2012; 20, 1444-8. doi: 10.1038/oby.2011.

19. Franssen R, Monajemi H, Stroes ES, et al. Obesity and dyslipidemia. Med Clin North Am. 2011; 95, 893902 PubMed . doi: 10.1016/j.mcna.2011.06.003.

20. Wang H, Xia N, Yang Y, et al. Influence of vitamin D supplementation on plasma lipid profiles: a meta-analysis of randomized controlled trials. Lipids Health Dis. 2012; 11, 42. doi: 10.1186/1476-511X-11-42.

21. Çizmecioğlu FM, Etiler N, Görmüş U, Hamzaoğlu O, Hatun S.. Hypovitaminosis D in obese and overweight schoolchildren. J Clin Res Pediatr Endocrinol. 2008;1:89-96.

22. Ergür AT, Berberoğlu M, Atasay B, Şıklar Z, Bilir P, Arsan S, et al. Vitamin D deficiency in Turkish mothers and their neonates and in women of reproductive age. J Clin Res Pediatr Endocrinol. 2009;1:266-9. doi: 10.4274/ jcrpe.v1i6.266. Epub 2009 Nov 3.

23. Third Report of the National Cholesterol Education Program (NCEP) Expert Panel on Detection, Evaluation, and Treatment of High Blood Cholesterol in Adults (Adult Treatment Panel III) final report. Circulation. 2002;106:3143-421 PubMed .

24. Lips P: Vitamin D deficiency and secondary hyperparathyroidism in the elderly: consequences for bone loss and fractures and therapeutic implications. Endorr Rev. 2001, 22:477-501 PubMed . doi: 0163$769 \mathrm{X} / 01 / \$ 03.00 / 0$

25. Nesibe Andıran, Nurullah Celik, Halise Akca, Guzide Doğan. Vitamin D Deficiency in Children and Adolescents. J Clin Res Pediatr Endocrinol. 2012;4(1):25-29. doi: $10.4274 /$ jcrpe. 574 .

26. Atli T, Gullu S, Uysal AR, Erdogan G: The prevalence of vitamin $\mathrm{D}$ deficiency and effects of ultraviolet light on vitamin D levels in elderly Turkish population. Arch Gerontol Geriatr. 2005, 40:53-60.

27. Alagöl F, Shihadeh Y, Boztepe H, Tanakol R, Yarman S, Azizlerli H, Sandalci O: Sunlight exposure and vitamin $\mathrm{D}$ deficiency in Turkish women. J Endocrinol Invest. 2000, 23:173-177 PubMed .
28. Guzel R, Kozanoglu E, Guler-Uysal F, Soyupak S, Sarpel T: Vitamin D status and bone mineral density of veiled and unveiled Turkish women. J Womens Health Gend Based Med. 2001, 10:765-770.

29. Yanowski, S.Z., \& Yanowski, J.A. Obesity. N Engl J Med. 2002; 346:591-602 PubMed .

30. Jia WP, Xiang KS, Chen L, et al. Epidemiological study on obesity and its comorbidities in urban Chinese older than 20 years of age in Shanghai, China. Obes Rev. 2002;3:157-65 PubMed .

31. Bagriacik, N., Onat, H., Ilhan, B., Tarakci, T., Oşar, Z., Ozyazar, O., Hatemi, H.H., \& Yildiz, G. Obesity profile in Turkey. Int J Diabetes \& Metabolism. 2009;17: 5-8 PubMed .

32. Ernst B, Thurnheer M, Schmid SM, et al. Seasonal variation in the deficiency of 25-hydroxyvitamin $\mathrm{D}(3)$ inmildly to extremely obese subjects. Obes Surg. 2009; 19, 180-3 PubMed . doi: 10.1007/s11695-008-9636-2.

33. Rodriguez-Rodriguez E, Navia B, Lopez-Sobaler AM, et al. Vitamin D in overweight/obese women and its relationship with dietetic and anthropometric variables. Obesity (Silver Spring). 2009; 17, 778-82. doi: 10.1038/oby.2008.649.

34. Harkness LS, Bonny AE. Calcium and vitamin D status in the adolescent: key roles for bone, body weight, glucose tolerance, and estrogen biosynthesis. $J$ Pediatr Adolesc Gynecol. 2005; 18: 305-311.

35. Berkey CS, Rockett HRH, Willet WC, Colditz GA. Milk, dairy fat, dietary calcium, and weight gain: a longitudinal study of adolescents. Arch Pediatr Adolesc Med. 2005; 159: 543-550.

36. Troiano RP, Flegal KM. Overweight children and adolescents: description epidemiology, and demographics. Pediatrics. 1998; 101(3): 497 PubMed -504.

37. Kull M, Kallikorm R, Lember M. Body mass index determines sunbathing habits: implications on vitamin D levels. Intern Med J. 2009; 39: 256-258 PubMed . doi: 10.1111/j.1445-5994.

38. Pittas AG, Sun Q, Manson JE, Dawson-Hughes B, Hu FB. Plasma 25-hydroxyvitamin D concentration and risk of incident type 2 diabetes in women. Diabetes Care. 2010;33(9):2021 PubMed -2023. doi: 10.2337/ dc10-0790.

39. Robinson JG, Manson JE, Larson J, Liu S, Song Y, Howard BV, et al. Lack of association between $25(\mathrm{OH})$ $\mathrm{D}$ levels and incident type 2 diabetes in older women. Diabetes Care. 2011;34(3):628 PubMed -634. doi: $10.2337 / \mathrm{dc} 10-1632$

40. Ford ES, Zhao G, Tsai J, Li C. Associations be- 
tween concentrations of vitamin $\mathrm{D}$ and concentrations of insulin, glucose, and HbA1c among adolescents in the United States. Diabetes Care. 2011;34(3):646-648. doi: $10.2337 /$ dc10-1754.

41. Holick MF. Vitamin D: evolutionary, physiological and health perspectives. Curr Drug Targets. 2011;12(1):4 PubMed -18.

42. Zittermann A, Gummert JF, Borgermann J. Vitamin D and mortality. Curr Opin Clin Nutr Metab Care. 2009;12(6):634-639. doi: 10.1097/ MCO.0b013e3283310767.

43. Gupta AK, Brashear MM, Johnson WD. Prediabetes and Prehypertension in healthy adults are associated with low vitamin D levels. Diabetes Care. 2011;34(3):658 PubMed -660. doi: 10.2337/dc10-1829.

44. Procopio M, Borretta G. Derangement of glucose metabolism in hyperparathyroidism. J Endocrinol Invest. 2003;26(11):1136-1142.

45. Pittas AG, Harris SS, Stark PC, Dawson-Hughes B. The effects of calcium and vitamin $\mathrm{D}$ supplementation on blood glucose and markers of inflammation in nondiabetic adults. Diabetes Care. 2007; 30:980- PubMed ;986.

46. Boer IH, Tinker LF, Connelly S, et al. Calcium plus vitamin $\mathrm{D}$ supplementation and the risk of incident diabetes in the Women's Health Initiative. Diabetes Care. 2008; 31:701- PubMed ;707. doi: 10.2337/dc07-1829.

47. Chiu KC, Chu A, Go VLW, Saad MF. Hypovitaminosis $\mathrm{D}$ is associated with insulin resistance and $\beta$-cell dysfunction. Am J Clin Nutr. 2004;39:820-825.

48. Scragg R, Holdaway I, Singh V, Metcalf P, Baker J, Dryson E. Serum 25-hydroxyvitamin D3 levels de- creased in impaired glucose toleranceand diabetes mellitus. Diabetes Res Clin Pract. 1995;39:181-188.

49. Hypponen E, Power C. Vitamin D status and glucose homeostasis in the 1958 British birth cohort: the role of obesity. Diabetes Care. 2006;39:2244-2246.

50. Hypponen E, Boucher BJ, Berry DJ, Power C. 25-Hydroxyvitamin D, IGF-1, and metabolic syndrome at 45 years of age: a cross-sectional study in the 1958 British Birth Cohort. Diabetes. 2008; 57:298- PubMed ;305.

51. Reis JP, von Muhlen D, Miller ER 3rd. Relation of 25-hydroxyvitamin D and parathyroid hormone levels with metabolic syndrome among US adults. Eur J Endocrinol. 2008; 159:41- PubMed ;48. doi: 10.1530/EJE08-0072.

52. Taylor WH, Khaleeli AA. Coincident diabetesmellitus and primary hyperparathyroidism. Diabetes Metab Res Rev. 2001;17(3):175 PubMed -80.

53. Lee DM, Rutter MK, O'Neill TW, Boonen S, Vanderschueren D, et al. Vitamin D, parathyroid hormone and the metabolic syndrome in middle-aged and older European men. Eur J Endocrinol. 2009;161: $947-$ 954. doi: 10.1530/EJE-09-0496.

54. Kamycheva E, Sundsfjord J, Jorde R. Serum parathyroid hormone level is associated with body mass index. The 5th Tromso study. Eur J Endocrinol. 2004;151: 167-172 PubMed .

55. Hjelmesaeth J, Hofsø D, Aasheim ET, Jenssen T, Moan J, et al. Parathyroid hormone, but not vitamin D, is associated with the metabolic syndrome in morbidly obese women and men: a cross-sectional study. Cardiovasc Diabetol. 2009;8: 7. doi: 10.1186/1475-2840-8-7. 